\title{
Deprem Kayıtları Kullanılarak Muğla-Milas Derince Barajının Dinamik Özelliklerinin Belirlenmesi
}

\author{
Erkan Ateş ${ }^{1}$, Turgay Kuru ${ }^{1}$,Recep Kemal Aydın ${ }^{2}$ \\ ${ }^{1}$ Afet ve Acil Durum Yönetimi Başkanlığı Deprem Dairesi Başkanlığı, ANKARA \\ ${ }^{2}$ DSİ 21. Bölge Müdürlüğ̈̈, AYDIN
}

20.03.2019 Geliş/Received, 22.10.2019 Kabul/Accepted

\section{$\ddot{\mathbf{O} z}$}

Muğla Milas ilçesinde Söke Milas Karayolu Derince Çayı köprüsünün 3,5 km kuzeyinde Derince Çayı üzerinde yer alan Derince Barajı, önyüzü beton kaplı kum çakıl dolgu tipinde olup temelden yüksekliği 67 m'dir. Baraj 2014 yılında hizmete açılmış olup, 2015 yılında barajın deprem altındaki yapısal durum ve performansını izlemek üzere bir adet gövde üzerine bir adet ana kayaya olmak üzere 2 adet ivmeölçer cihazı yerleştirilmiştir. Bu istasyonlar ile bir deprem anında barajın depremlere karşı vermiş olduğu tepki gözlenmiş olacaktır. 2017-2018 yıllarında Ege bölgesinde meydana gelen depremlerden anakaya ve baraj gövdesinde kurulu bulunan ivmeölçerler tarafından kaydedilen; lokasyonları farklı Mw>4.4 olan 9 adet deprem kaydı kullanılmıştır. Barajın dinamik özelliklerinin belirlemek amacıyla kaydedilen deprem sinyallerine referans yöntemine göre standart spektral oran (SSR) ve yatay/düşey spektral oran (HVSR) yöntemleri uygulanmıştır. Bu iki yöntemin analizleri sonucunda baraj gövdesine ait büyütmeler, baskın frekanslar belirlenmiştir. $\mathrm{Bu}$ yöntemin analizi sonucunda barajın hakim frekansı $2.36 \mathrm{~Hz}$ bulunmuş ve iki yöntem karşılaştırılmıştır.

Anahtar Kelimeler: baraj, deprem, spektral oran, hakim frekans, dinamik özellik

\section{Determination of Dynamic Properties of Muğla-Milas Derince Dam Using Earthquake Records}

\begin{abstract}
Derince Dam, which is located in $3.5 \mathrm{~km}$ north of Derince River Bridge of Derince River in Söke Milas Highway of Milas district of Muğla, is $67 \mathrm{~m}$ high from its base. The dam was put into service in 2014 and, two accelerometer devices, one on the bedrock and one on the body, were placed to monitor the structural status and performance of the dam during an earthquake in 2015. The reaction of the dam to earthquakes was planned to be observed during an earthquake with these stations. Nine earthquake records in different locations with $\mathrm{Mw}>4.4$ were recorded by accelerometers installed on the bedrock and dam body, were used during the earthquakes occurred in the Aegean region in the years of 2017 and 2018. Standard spectral ratio (SSR) and horizontal / vertical spectral ratio (HVSR) methods were applied to the recorded earthquake signals according to the reference method in order to determine the dynamic


characteristics of the dam. As a result of the analysis of these two methods, growths in dam body and dominant frequencies were determined. The analysis of this method indicated that the dominant frequency of the dam was $2.36 \mathrm{~Hz}$. These two methods were compared in the study.

Keywords: dam, earthquake, spectral ratio, dominant frequency, dynamic property

\section{Giriș}

Deprem oluştuğunda merkez üssünden yayılan sismik dalgalar yer yüzünde ana kayada veya yumuşak olan yer tabakalarında belirli sürelerde titreşim üretirler. Bu süre depremin büyüklüğüne, yerine, uzaklığına ve zemin özelliklerine göre farklılıklar gösterir. Yer hareketini inceleyebilmek için en temel yöntem ivmeölçer kayıtlarının analiz edilmesidir. Yer-yapıda deprem dalgalarının büyütmesinin tespit edilmesinde kullanılan en geçerli yöntemlerden birisi ivme kayıtlarının incelenmesidir. Yer büyütmelerinin belirlenmesinde Standart Spektral Oran (SSR) yöntemi (Borcherdt, 1970), Yatay Düşey Spektral Oran (HVSR) yöntemleri (Nakamura, 1989) kullanılmaktadır. SSR yönteminin temel esası, büyütmesi belirlenmek istenen deprem istasyonuna yakın olan bir ana kaya istasyonuna oranlanması esasına dayanır. Büyütmenin hesaplanabilmesi için 2 istasyonun aynı deprem kayıtlarını kayıt etmesi gerekmektedir. İstasyonlar arası mesafenin ise episantr uzaklığından az olması gerekmektedir (Steidl ve ark., 1996). HVSR yöntemi ise referans istasyonu gerekmediğinden SSR yöntemine oranla daha kullanışlıdır. Bu yöntemin temeli, deprem kayıtlarının yatay bileşenlerin düşey bileşene oranlanması prensibine dayanır. Yer etkisini belirlemek için 1995 yılında meydana gelen Afyon Dinar depreminden sonra kurulan ivmeölçer istasyonu kayıtlarının analizleri (Yalçınkaya ve Alptekin, 2003), Bursa'da TÜBİTAK projesiyle yerleştirilen altı ivmeölçer istasyonunda beş farklı ivme kaydı analiz edilerek (Yalçınkaya, 2005) araştırılmıştır. Benzer bir çalışma ise İzmir ili içerisinde kurulan ivmeölçer istasyonları kayıtları kullanılarak (Gök ve ark., 2012) yer özellikleri belirlenmeye çalışılmıştır. Kocaeli ilinde ise binada ve yerde bulunan ivmeölçer istasyonları kullanılarak (Ateş ve Uyanık, 2019) 2 farklı yöntem ile yapıya ve yere ait dinamik özellikleri belirlemeye çalışmışlardır.

Deprem esnasından yapıda hasar oluşma olasılığının belirlenebilmesi için yer etkisinin yanında yapı periyodunun belirlenmesi gerekmektedir (Uyanık, 2015). Bir barajın sağlamlığı ve kullanılabilirliği, doğal ya da insan yapımı olaylar, depremler, aşırı çalışma seviyeleri, kontrolsüz yapısal değişiklikler ve diğer çeşitli etkilerle önemli ölçüde azalabilir. Barajların izlenmesi, yapının kendisini etkilemeden, deprem altında yapısal durum ve performansı izlemek için yenilikçi bir yöntem olan Yapı Sağlığı ve Müdahale İzleme'nin bir koludur. Temel kavram, izin verilen performans kriterlerinin aşılmasını tespit etmek, yapısal davranışı tanımlamak ve doğrulamak için ivmeölçerleri baraja yerleştirmektir. Elde edilen verilerin sistem tarafından kullanılması, bir barajın yer özellikleri, büyük baraj yapısı içindeki sönümlenme, temel veya gövdeye doğru yol boyunca yer hareketinin güçlendirilmesi, yapı içindeki dalga yayılımı, doğal frekanslar, mod şekilleri vb. özellikleri ile ilgili bilgi verebilir.

Yerin dinamik özelliklerinin belirlenmesinde jeofizik yöntemler etkin olarak kullanılmaktadır (Salem, 2000; Jafari ve ark., 2002; Othman, 2005; Ulugergerli ve Uyanık 2007; Uyanık ve Ulugergerli, 2008; Dikmen, 2009; Özçep ve ark., 2010; Uyanık, 2010; Uyanık, 2011; Uyanık, 2015; Karabulut ve ark., 2012; Uyanık ve ark., 2013a; Uyanık ve ark., 2013b). Bununla birlikte son yıllarda mevcut yapıların da dinamik özelliklerini belirlemek için jeofizik yöntemler kullanılmaya başlanmıştır (Uyanık ve ark., 2011; Uyanık ve ark., 2012; Öziçer ve Uyanık, 
2017; Sabbağ ve Uyanık, 2017; Uyanık, 2018; Özçelik ve Gelişli, 2018; Okur ve ark., 2019). Ancak mevcut yapılarda deprem kayıtları elde edilerek yapının dinamik analizi nadiren yapılmaktadır (Ateş ve Uyanık, 2019). Bu çalışma özellikle barajlardaki ivmeölçerler tarafından kaydedilen gerçek deprem kayıtları ile barajların dinamik özelliklerini belirlemesi yönünden farklı bir yaklaşım ortaya çıkaracaktır. Muğla ili Milas ilçesi Derince Barajına 2015 yılında barajın deprem altındaki yapısal durum ve performansını izlemek üzere bir adet gövde üzerine, bir adet paleozoyik yaşlı metamorfik ana kaya olacak şekilde 2 adet ivmeölçer cihazı kurulmuştur. Bu cihazların kaydettiği farklı büyüklük ve uzaklıktaki 9 adet deprem verisi kullanılarak iki farklı yöntemle barajın baskın salınım frekansı belirlenmeye çalışılmıştır. Bu çalışmada gerçek deprem kayıtları kullanılarak iki farklı yöntem (HVSR ve SSR) ile baraj dinamik özelliklerinin belirlenmesiyle diğer çalışmalardan farklı bir yaklaşım ortaya konulmuştur. Ayrıca bu çalışmayla iki yöntem karşılaştırılmıştır.

\section{2. Çalışma Alanı}

\subsection{Derince Barajı}

Derince Barajı Muğla ili Milas ilçesi Derince yerleşim merkezi sınırları içerisinde, Milas ilçesinin $20 \mathrm{~km}$ kuzeybatısında Derince'nin 2 km kuzeyinde yer almaktadır. Baraj yeri ve göl alanındaki jeolojik birimler; paleozoyik mikaşist, kuvarsit, gnays, kuvaterner yaşlı eski alüvyon, killi yamaç molozu ve alüvyondan oluşmaktadır.

Malzeme ocaklarında ortaya çıkan çeşitli sebeplerden dolayı gövde tipi kil çekirdekli kaya dolgu tipinden ön yüzü beton kaplamalı kum-çakıl dolgu tipine dönüştürülen Derince Barajı 2014 yılı içerisinde hizmete açılmış olup, 2015 yılında bir adet gövdeye bir adet ana kayaya olmak üzere toplam 2 adet ivmeölçer istasyonu yerleştirilmiştir. Barajlara kurulan ivmeölçerler İsviçre menşeli üç bileşenli Force balance tipi GMSPLUS marka cihazlardır. Değerlendirme yapılan Derince Barajının genel görünüşü ve üzerine yerleştirilen deprem ivmeölçer cihazların Şekil 2.1'de gösterilmiştir. İvmeölçerlerin Doğu-Batı (EW) yönü baraj ekseninin uzun aksını, Kuzey-Güney (NS) yönü baraj eksenine dik olarak (kısa eksene) yerleştirilmiştir. Anakaya olarak kurulan istasyon şistler üzerine kurulmuştur. Bu çalışmada kullanılan 2 farklı yöntemde bu cihazların kaydettiği ivme verileri kullanılmıştır. 


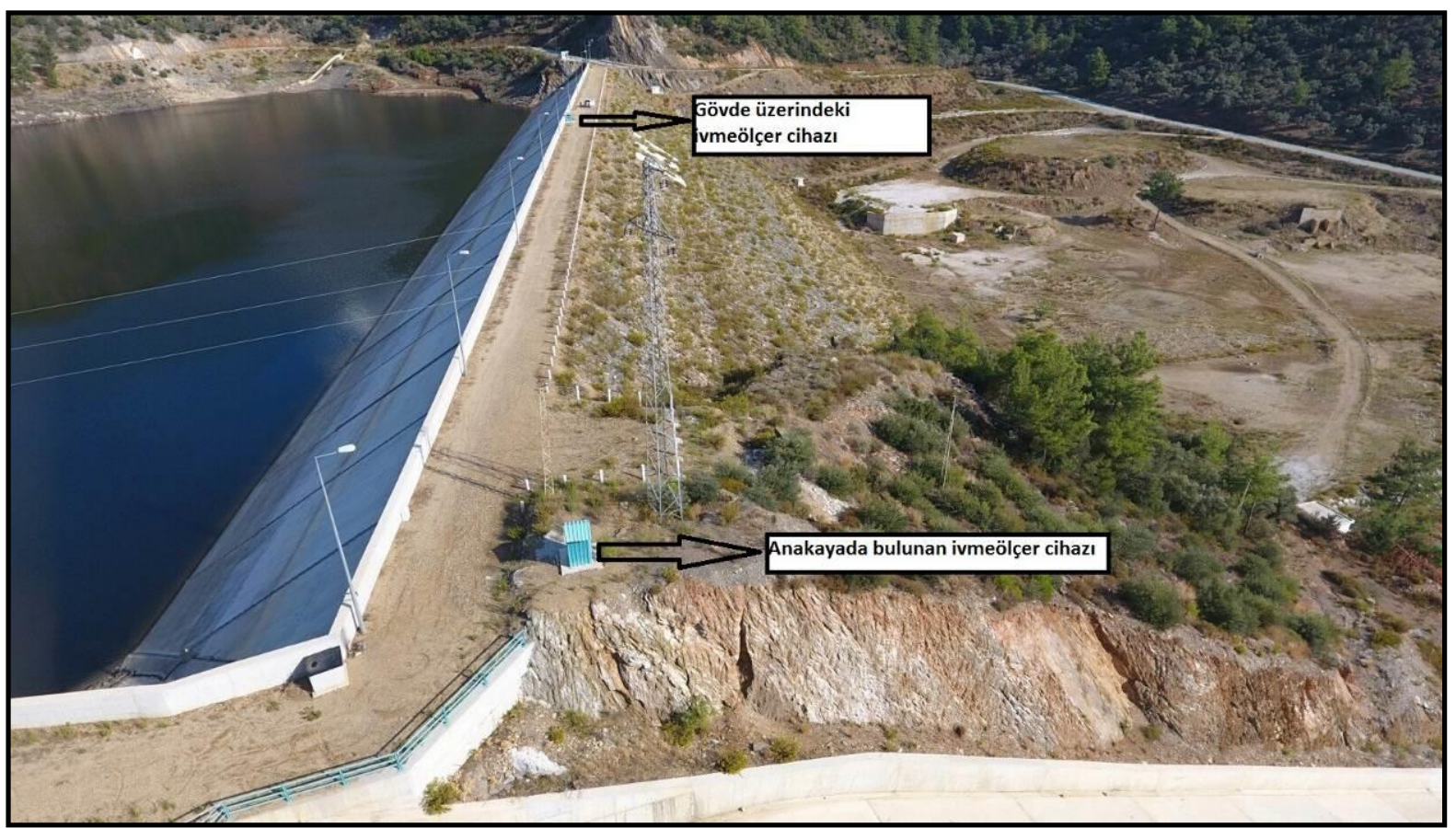

Şekil 2.1. Derince barajı ve kurulan ivmeölçer istasyonları

\subsection{Bölgenin Depremselliği}

Barajın bulunduğu bölgede birçok aktif fay bulunmaktadır. Şekil 2.2'de barajın inşa edildiği bölgenin $150 \mathrm{~km}$ yarıçapında meydana gelen ve aletsel dönemde (1900 yıldan günümüze) kaydedilmiş moment büyüklügüu 4'den büyük depremler haritalanmıştır. Görüleceği üzere bölge deprem aktivitesi açısından son derece hareketlidir. Aletsel dönemden günümüze kadar barajın $150 \mathrm{~km}$ yarıçapındaki alanda büyüklüğü 4'den büyük 1236 adet deprem meydana gelmiştir. Bu depremlerin büyüklüklerine göre sıralaması Şekil 2.3'te gösterilmiştir.

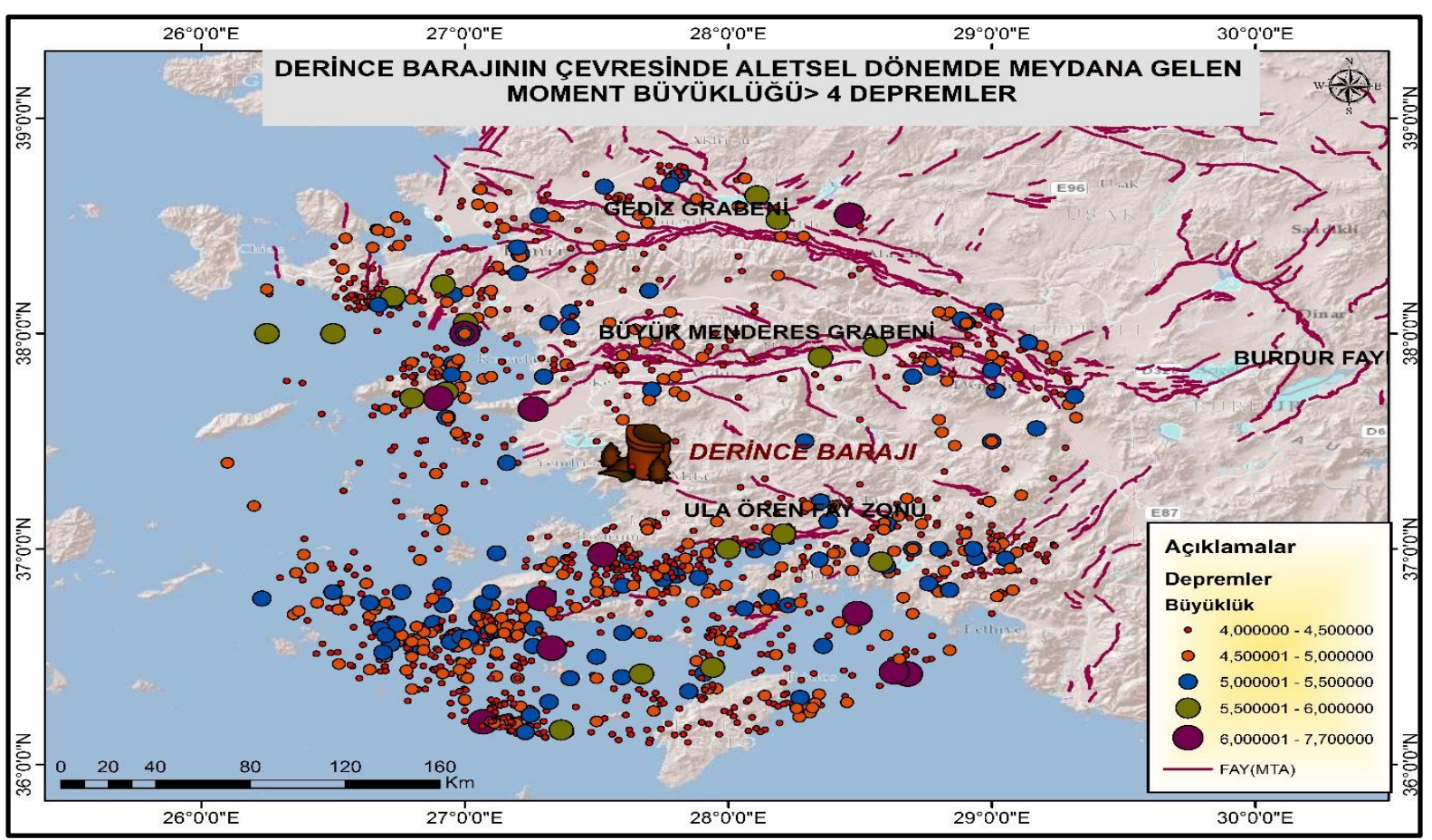

Şekil 2.2. Derince barajının $150 \mathrm{~km}$ yarıçap içerisinde meydana gelen depremler 


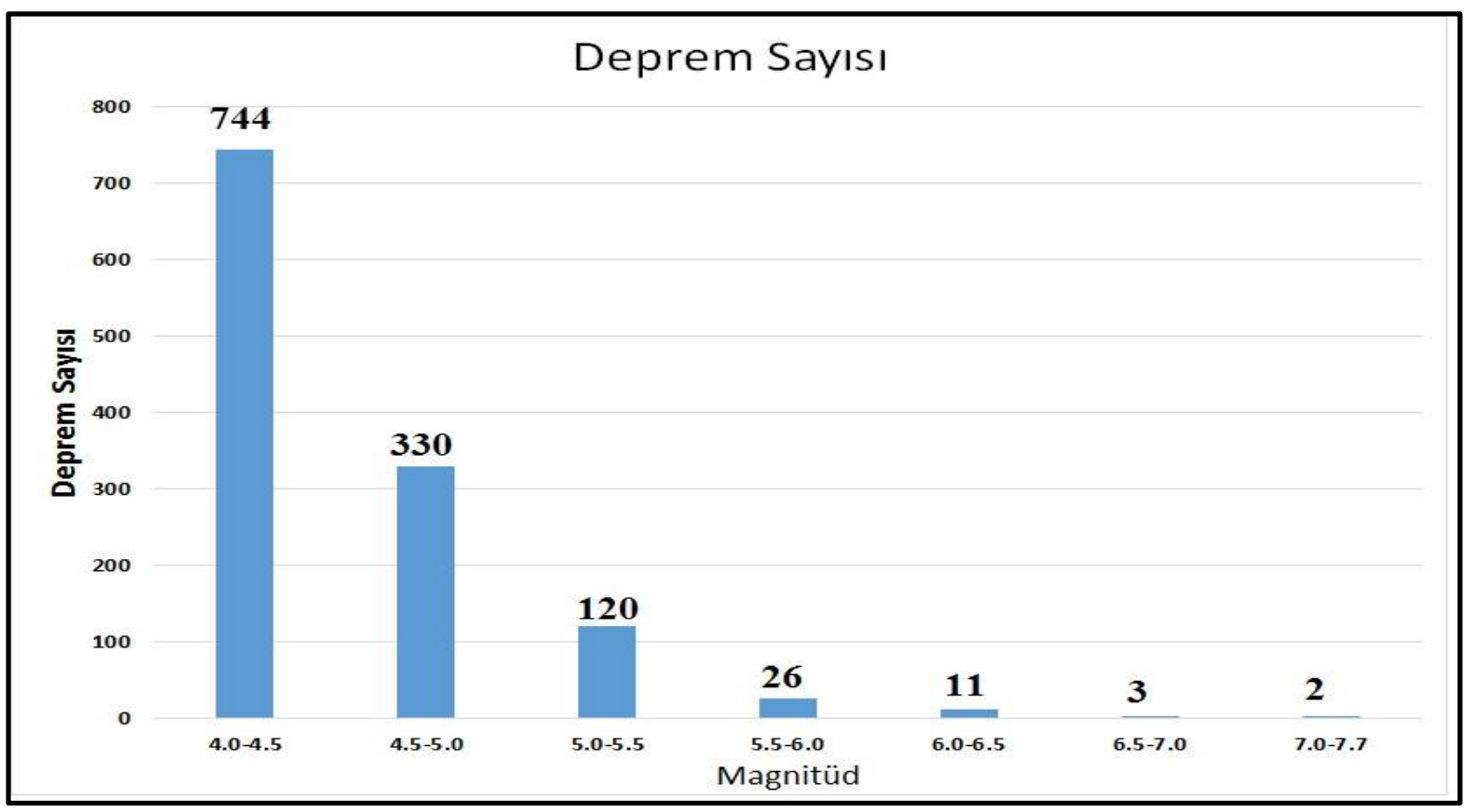

Şekil 2.3. 1900 yılından günümüze baraj çevresinde meydana gelen depremlerin büyüklüklerine göre siralanmas 1

Çalışma alanının kuzeyinde barajı etkileyecek Gediz ve Büyük Menderes Grabenlerine ait diri faylar bulunmaktadır. Barajın güneyinde ise Ula-Ören fay zonu bulunmakta olup karadaki toplam uzunluğu 60 km'dir. Şekil 2.2'de görülen depremlerin büyük çoğunluğu belirtilen fay zonlarında meydana gelmiştir.

\section{3. Çalışmada Kullanılan Depremler}

Derince barajının yapı sağlığının izlenmesi amacıyla 2015 yılında kurulan ivmeölçer istasyonları kurulduğu günden bu yana farklı büyüklük ve uzaklıkta birçok deprem kaydetmiştir. Bu depremlerden en büyüğü istasyonlara $53 \mathrm{~km}$ mesafede 20.07.2017 tarihinde meydana gelen büyüklüğü 6.5 olan Bodrum depremidir. Bu deprem kaydı cihazların kaydettiği en büyük ivme kaydıdır. Bu depremin etkili süresi baraj gövdesinde yaklaşık olarak 20 sn'dir. Şekil 2.4'te barajın gövdesinde uzun ekseninde (DB) ve kayada hissedilen etkili süre gösterilmiştir.

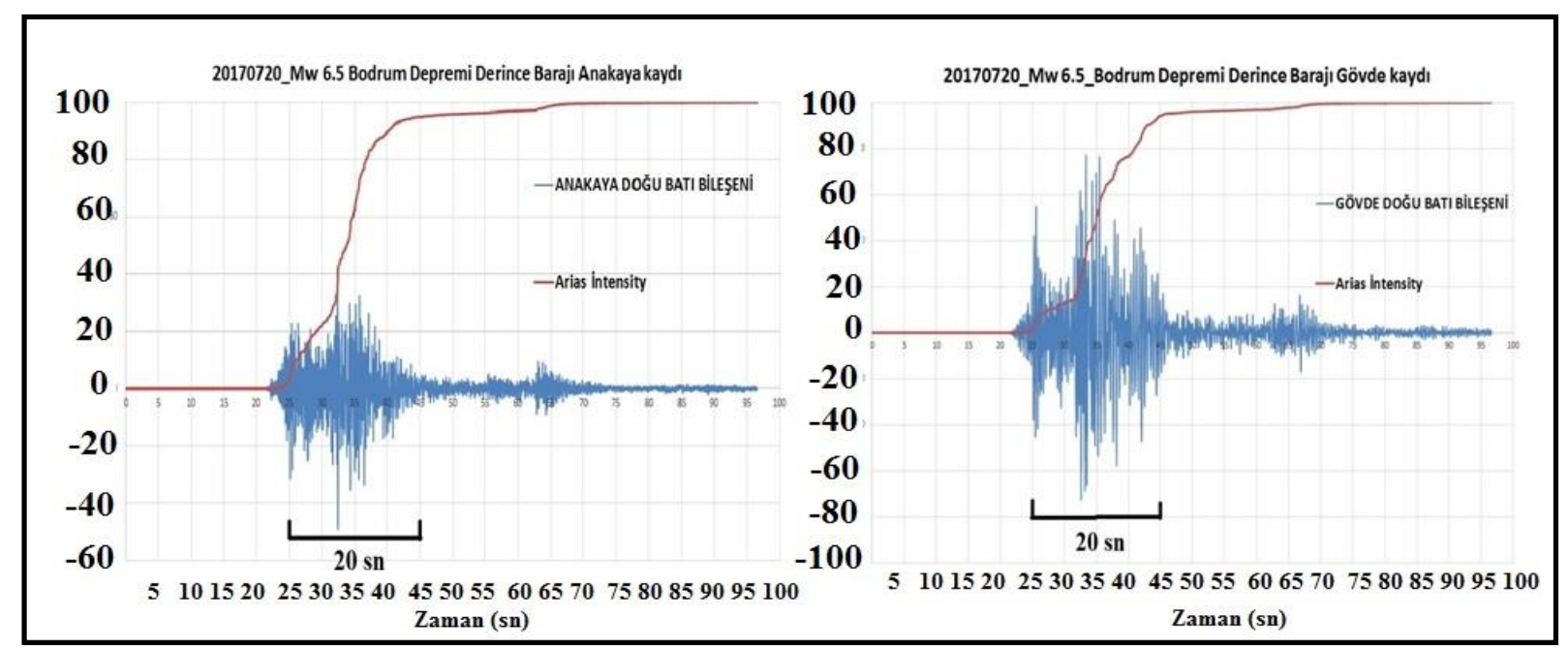

Şekil 2.4. Bodrum depreminin etkili süresi 
Bu çalışmada iki farklı yöntem kullanılmıştır. Standart Spektral Oran (SSR) yönteminde bu depremlerden 2 istasyon (ana kayada ve baraj gövdesinde) tarafindan ortak olarak kaydedilen Mw>4.4 9 adet deprem kaydı kullanılmıştır. SSR yönteminde iki cihaz tarafından kaydedilen deprem dalgaların geçtiği dalga yollarının aynı olması sebebi ile yol etkisi benzer olduğu kabul edilmiştir.

Yatay Düşey Spektral Oran (HVSR) yönteminde ise referans istasyonu gerekmediğinden yalnızca baraj gövdesinde bulunan ivmeölçer istasyonu tarafından kayıt edilen 9 adet deprem kaydı kullanılmıştır. İki farklı yöntemde kullanılan depremlerin enlem, boylam ve meydana geldiği tarihler Çizelge 2.1 'de ve Şekil 2.5 'de gösterilmiştir. İki yöntemde de aynı 9 deprem kaydı kullanılmıştır.

Kullanılan kayıtların tamamı Türkiye Cumhuriyeti İçişleri Bakanlığı'na bağlı olan Afet ve Acil Durum Yönetimi Başkanlığı Deprem Dairesi Başkanlığı tarafından işletilen veri tabanından alınmıştır (Anonim, 2019).

Çizelge 2.1. Çalışmada kullanılan depremlere ait parametreler

\begin{tabular}{|c|c|c|c|c|c|c|}
\hline Sira & Enlem & Boylam & Tarih & Büyüklük & $\begin{array}{c}\text { Odak } \\
\text { Derinliği(km) }\end{array}$ & $\begin{array}{c}\text { Derince Ba- } \\
\text { rajına } \\
\text { uzakliğ }(\mathrm{km})\end{array}$ \\
\hline 1 & 36.9740 & 27.5230 & 20.07 .2017 & 6.5 & 7.80 & 53 \\
\hline 2 & 36.9576 & 27.6236 & 08.08 .2017 & 5.1 & 11.03 & 54 \\
\hline 3 & 36.9410 & 27.3320 & 21.07 .2017 & 5.0 & 37.50 & 62 \\
\hline 4 & 37.1140 & 27.6890 & 13.08 .2017 & 4.8 & 22.60 & 37 \\
\hline 5 & 37.1208 & 27.6990 & 14.08 .2017 & 4.7 & 6.92 & 36 \\
\hline 6 & 36.9170 & 27.2300 & 24.09 .2017 & 4.5 & 9.20 & 69 \\
\hline 7 & 36.3163 & 28.4438 & 07.11 .2017 & 4.4 & 41.89 & 143 \\
\hline 8 & 37.1146 & 28.6045 & 24.11 .2017 & 5.1 & 24.46 & 92 \\
\hline 9 & 37.6546 & 26.6698 & 26.07 .2018 & 4.5 & 4.50 & 89 \\
\hline
\end{tabular}




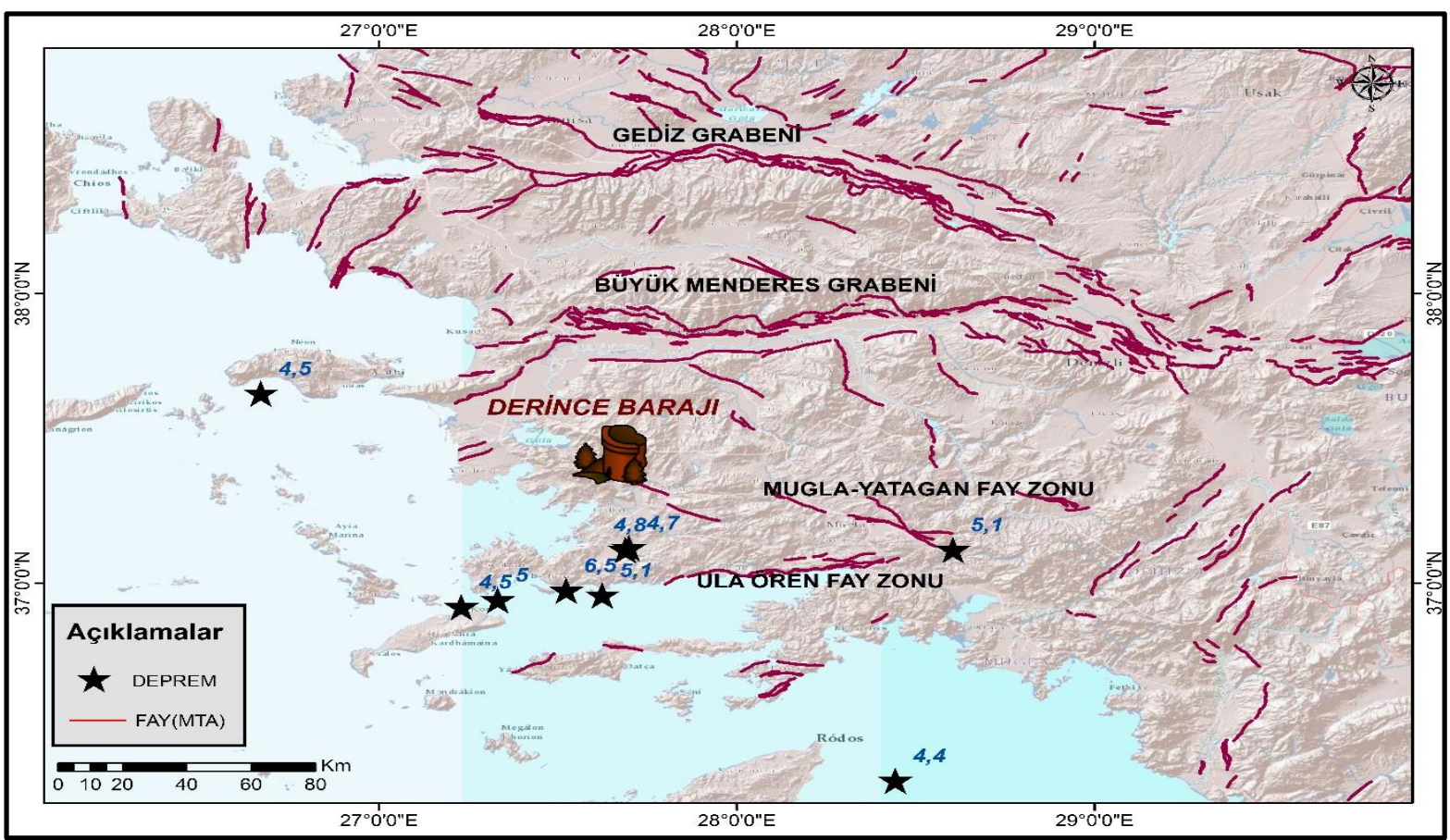

Şekil 2.5. Çalışmada kullanılan depremler

\section{Yöntemler}

\subsection{Standart Spektral Oran Yöntemi}

Borcherdt tarafından ivmeölçer, hızölçer kayıtlarına uygulanan yöntem, yer etkisi hesaplanmak istenen noktanın, referans noktasına oranlanması prensibine dayanır (Borcherdt, 1970).

İvmeölçer yatay bileşen kayıtlarından S dalga fazının belli bir kısmı çıkarılarak Fourier Spektrumu alınır. Her istasyona ait yatay bileşen spektrumları birleştirilerek yön bağımlılığından kurtulur. Büyütmesi hesaplanmak istenen istasyon referans istasyona oranlanarak büyütme belirlenmektedir.

$$
\operatorname{Tf}(f)=H A(f) \div \operatorname{HK}(f)
$$

Eşitlik 1 ile belirtilen $\mathrm{H}_{\mathrm{A}}(\mathrm{f})$ alüvyon noktasına ait yatay bileşen genlik spektrumunu, $\mathrm{H}_{\mathrm{K}}(\mathrm{f})$ ise anakaya istasyonunun genlik spektrumlarını göstermektedir. 


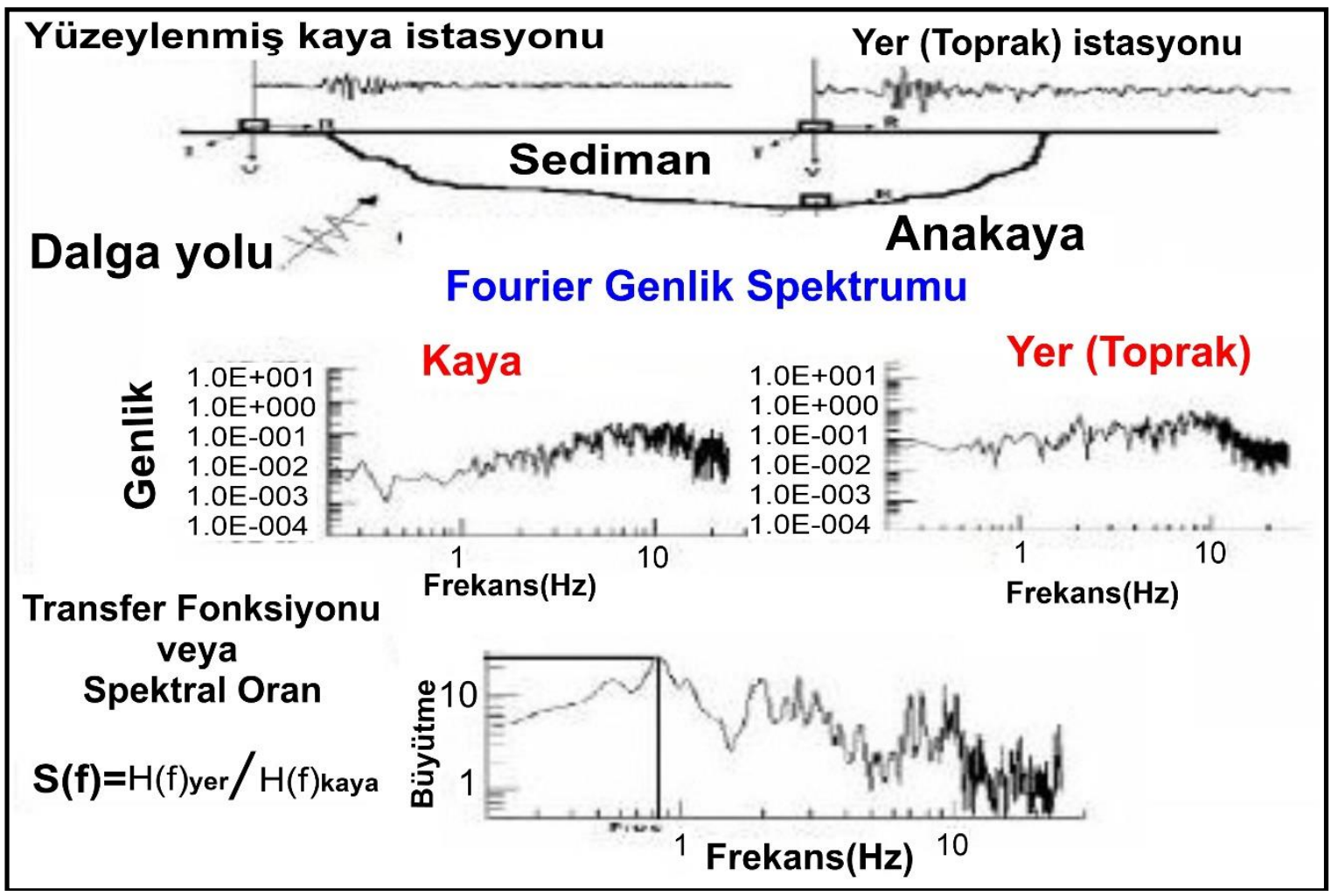

Şekil 3.1. SSR yöntemi analiz aşamaları (Ateş ve Uyanık, 2019)

\subsubsection{SSR Yönteminde Veri İşlem}

Çalışmada yapılan analizlerde GEOPSY yazılımı kullanılmıştır (Sesame, 2004). Kullanılan kayıtların örnekleme aralığı saniyede 100 örnektir. İki farklı cihaz kullanıldığından aygıt etkileri giderilmiştir. Depremin baraj gövdesindeki etkisini hesaplamak için S fazı kullanılmıştır. Belirlenen S fazından 5 sn uzunlukta pencereler kesilerek filtre işlemi uygulanmış ve veri uçları başından ve sonundan yuvarlatılarak hızlı Fourier dönüşümü kullanılarak genlik spektrumları alınmıştır. Yön bağımlılığından kurtulmak için yatay bileşenler birleştirilmiş ve gövde istasyonu anakaya istasyonuna oranlanmış, baskın frekans ve büyütme değerleri ortaya çıkarilmıştır.

Barajın 1. Mod frekansını ve büyütmesini tespit etmek için Çizelge 2.1'de verilen farklı Magnitüd ve episantr noktasına sahip 9 depreme ait 18 ivme kaydı kullanılmıştır.

Analiz sonuçlarında dört depreme ait örnek Şekil 3.2- Şekil 3.5' de sunulmuştur. Herbir şekilde a grafiğinde istasyonlardan alınan kayıtların ham verisi ve seçilen dalga fazı, b grafiğinde ana kayada ve baraj gövdesinde bulunan kayıtlarının genlik spektrumları, c grafiğinde ise gövde kaydının ana kayaya oranlanması sonucu bulunan transfer fonksiyonu görülmektedir. 


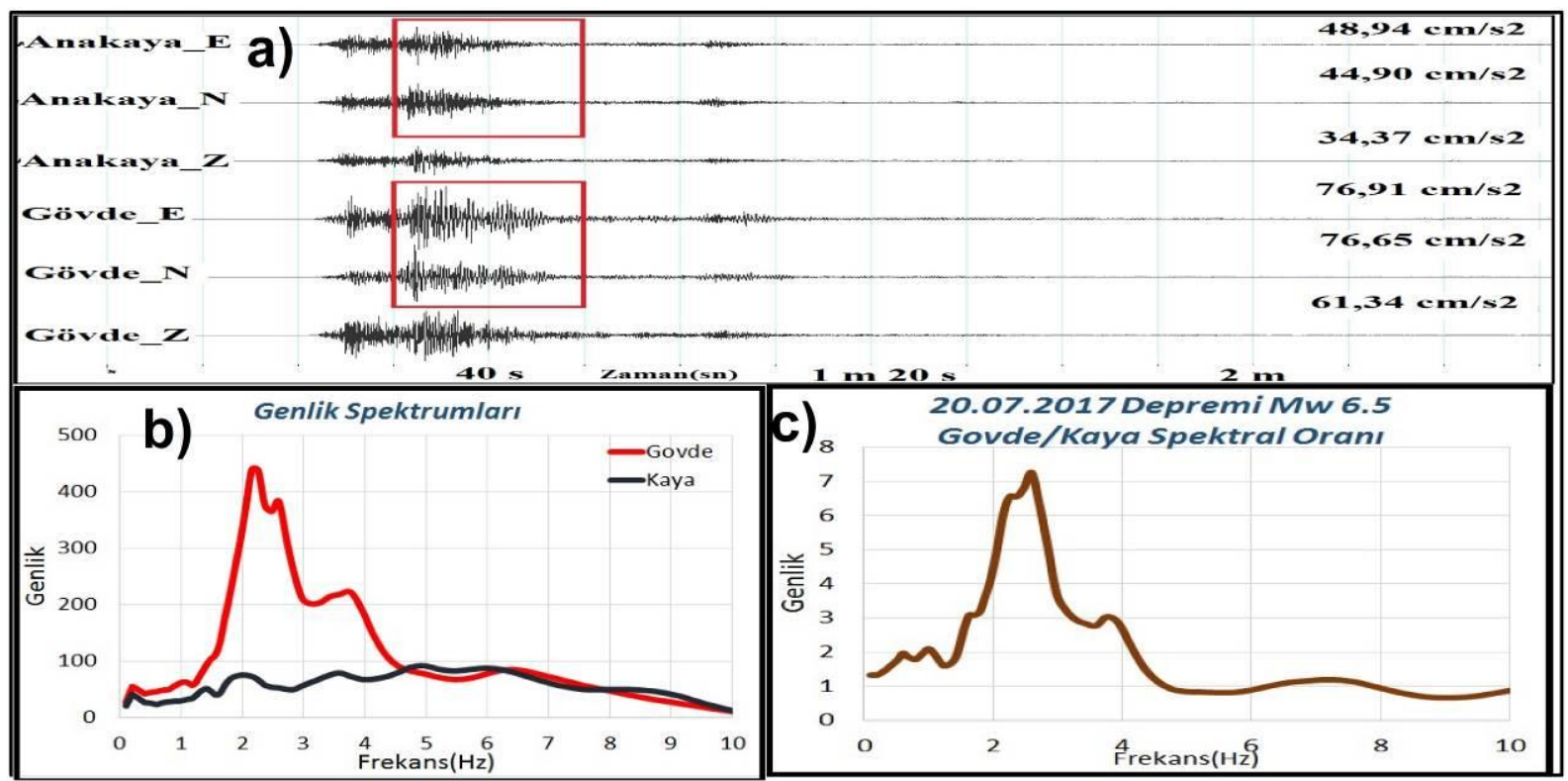

Şekil 3.2. a) 20.07.2017 Mw 6.5 deprem kayıtları (baraj gövdesi ve kaya), b) Birleştirilmiş yatay bileşen spektrumu, c) Gövdeye ait transfer fonksiyonu (gövde/kaya)

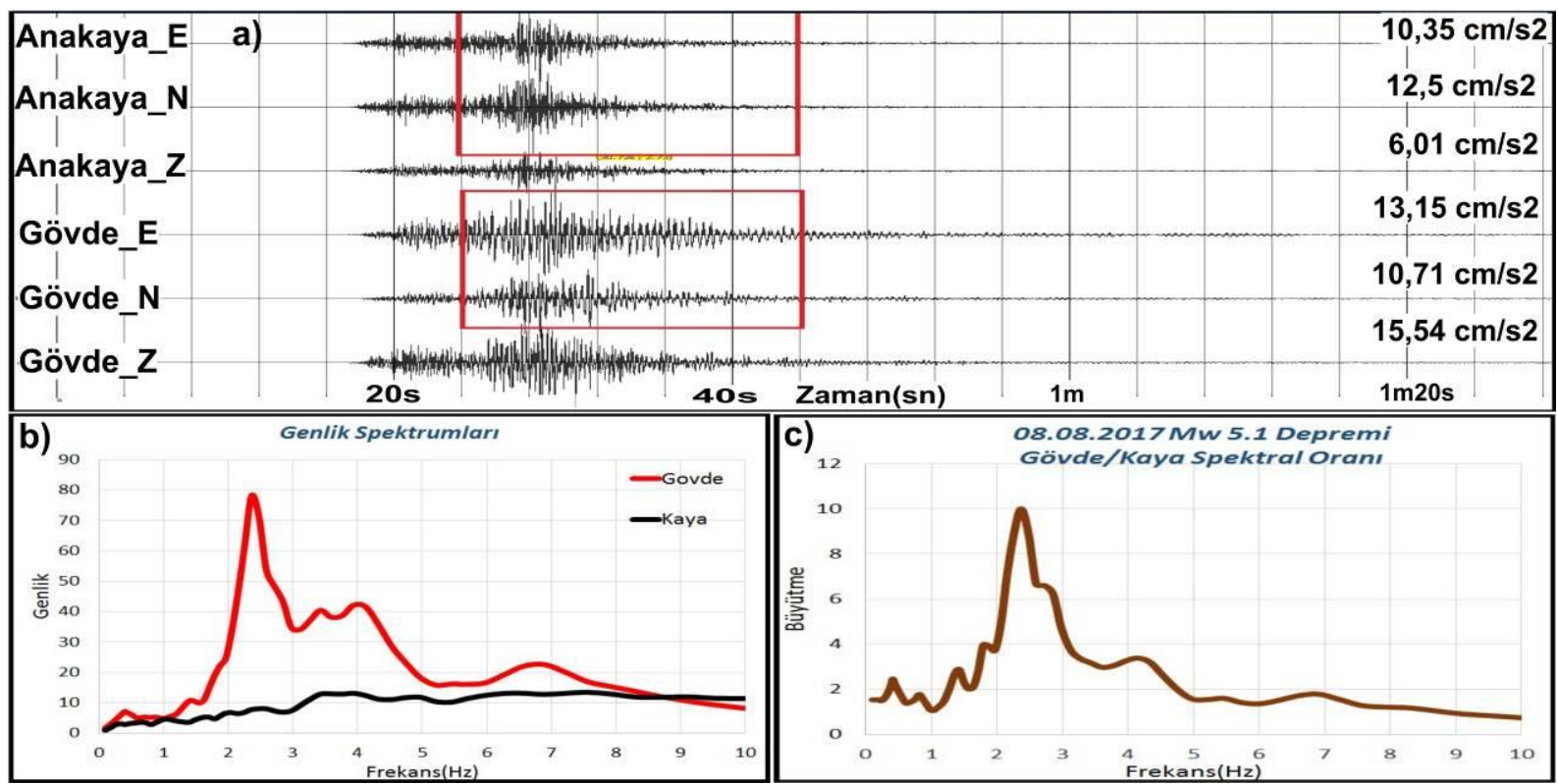

Şekil 3.3. a) 08.08.2017 Mw 5.1 deprem kayıtları (baraj gövdesi ve kaya), b) Birleştirilmiş yatay bileşen spektrumu, c) Gövdeye ait transfer fonksiyonu (gövde/kaya) 


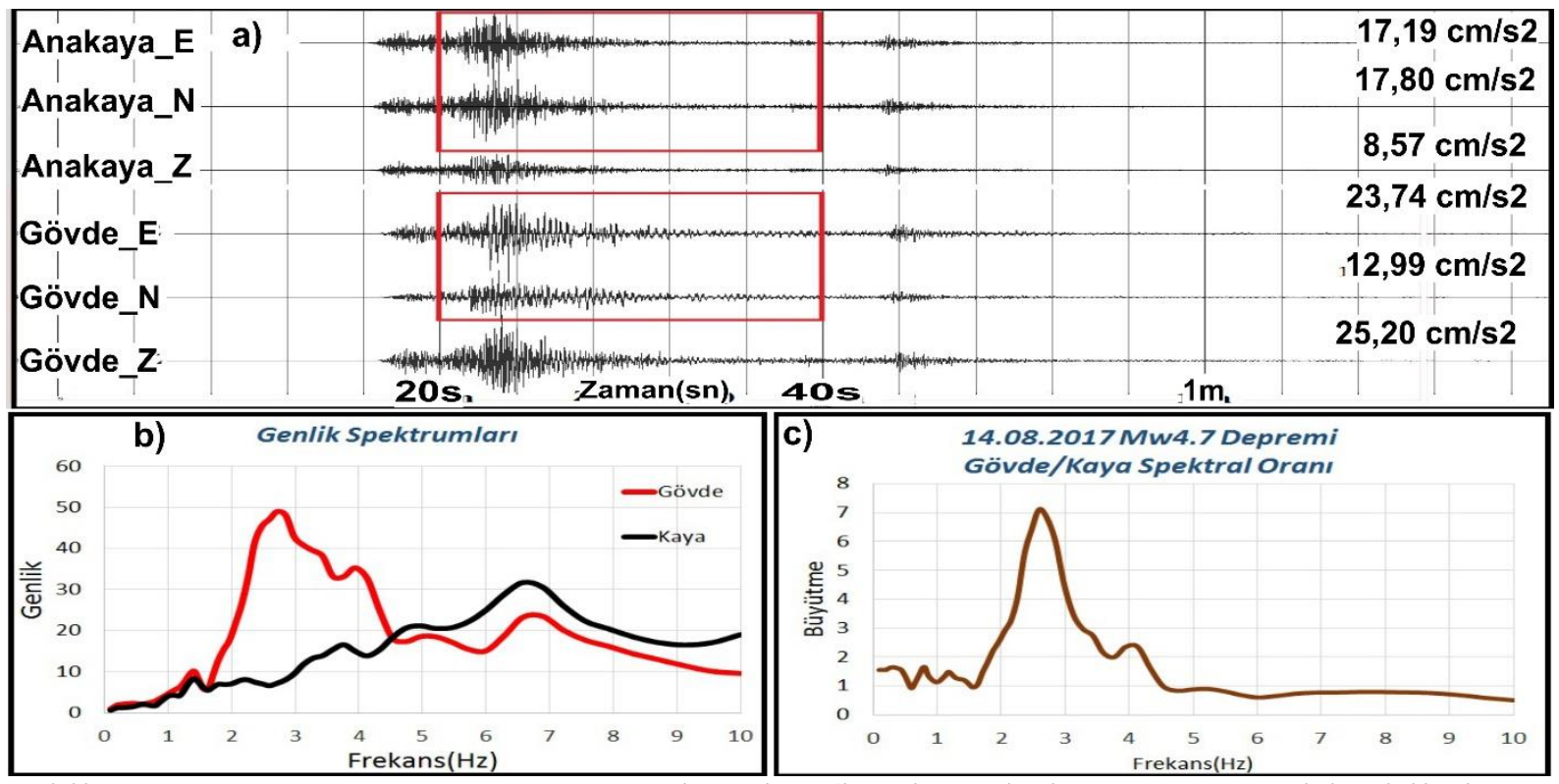

Şekil 3.4. a) 14.08.2017 Mw 4.7 deprem kayıtları (baraj gövdesi ve kaya), b) Birleştirilmiş yatay bileşen spektrumu, c) Gövdeye ait transfer fonksiyonu (gövde/kaya)

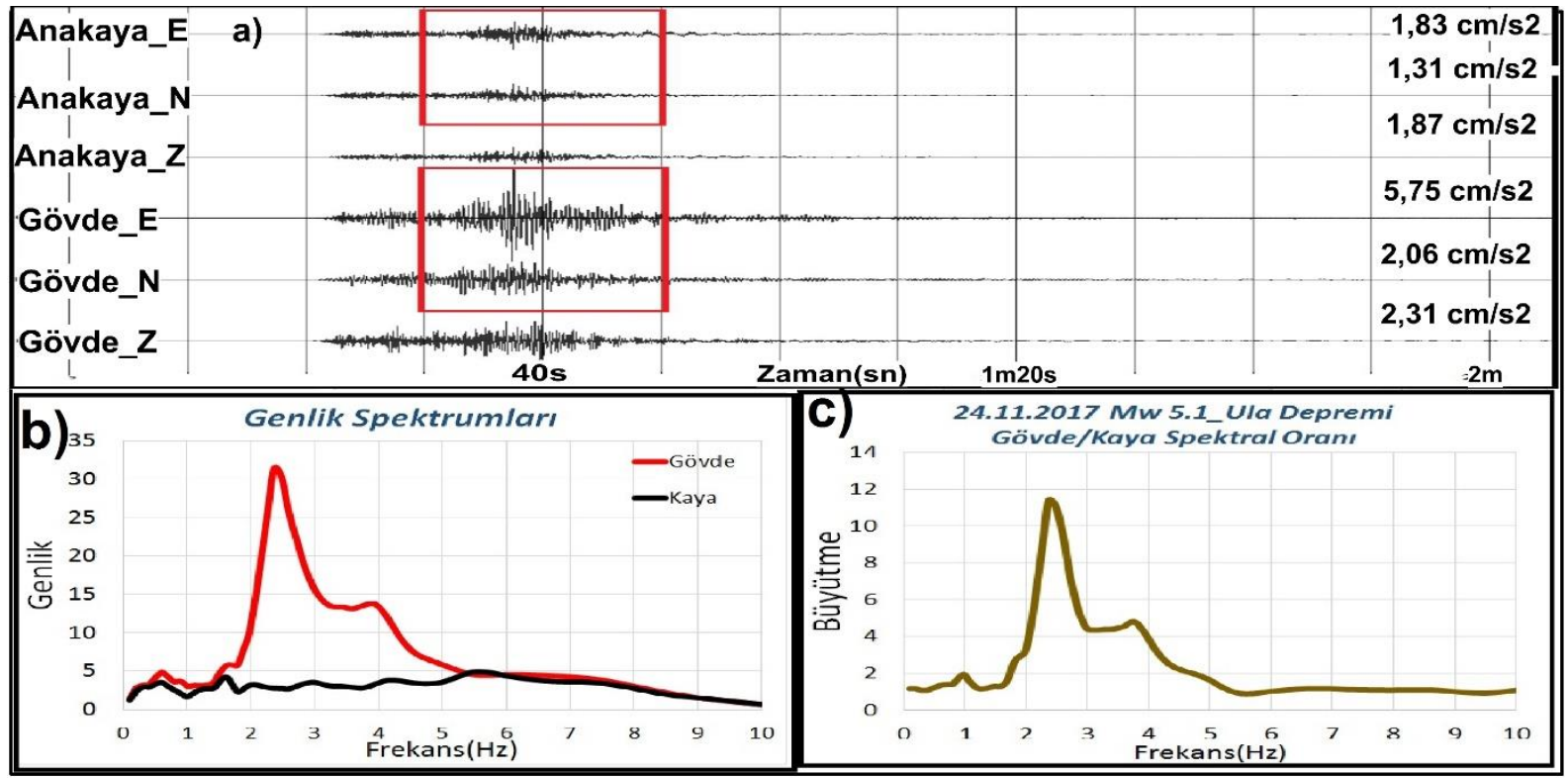

Şekil 3.5. a) 24.11.2017 Mw 5.1 deprem kayıtları (baraj gövdesi ve kaya), b) Birleştirilmiş yatay bileşen spektrumu, c) Gövdeye ait transfer fonksiyonu (gövde/kaya)

\subsubsection{SSR Yöntemi Sonuçları}

Yapılan 9 adet deprem çalışmasında baraj gövdesinde ve ana kaya da bulunan ivmeölçer istasyonlarının kayıtları SSR yöntemine göre değerlendirilmiş ve baraj gövdesine ait baskın salınım frekansı hesaplanmıştır.

Bu çalışmada baraj gövdesinin baskın salınım frekansı $2.36 \mathrm{~Hz}$ bulunmuştur. Baraj NS (kısa) ekseninde ortalama $2.7 \mathrm{~Hz}$, EW (uzun) ekseninde $2.42 \mathrm{~Hz}$ olarak hesaplanmıştır. Bu çalışmamızda yön bağımlılığından kurtulmak için eksenler birleştirilmiştir. Sonuçlar Çizelge 3.1'de belirtilmiştir. 
Çizelge 3.1. Depremlere ait analiz sonuçları

\begin{tabular}{|l|c|c|c|c|c|c|c|}
\hline \multicolumn{1}{|c|}{ Tarih } & $\begin{array}{c}\text { Büyüklük } \\
(\mathrm{Mw})\end{array}$ & $\begin{array}{c}\text { Istasyona } \\
\text { olan } \\
\text { Uzakl1k } \\
(\mathrm{km})\end{array}$ & $\begin{array}{c}\mathrm{f} \\
(\mathrm{E}-\mathrm{W}) \\
\mathrm{Hz}\end{array}$ & $\begin{array}{c}\mathrm{f} \\
(\mathrm{N}-\mathrm{S}) \\
\mathrm{Hz}\end{array}$ & $\begin{array}{c}\text { Frekans } \\
(\mathrm{f}) \mathrm{Hz}\end{array}$ & $\begin{array}{c}\text { Periyod(T0) } \\
\text { sn }\end{array}$ & Büyütme \\
\hline 20.07 .2017 & 6.5 & 53 & 2.25 & 2.60 & 2.25 & 0.44 & 6.7 \\
\hline 08.08 .2017 & 5.1 & 54 & 2.36 & 2.84 & 2.36 & 0.42 & 10.00 \\
\hline 21.07 .2017 & 5.0 & 62 & 2.84 & 2.84 & 2.84 & 0.35 & 6.9 \\
\hline 13.08 .2017 & 4.8 & 37 & 2.47 & 2.71 & 2.69 & 0.37 & 7.0 \\
\hline 14.08 .2017 & 4.7 & 36 & 2.59 & 2.42 & 2.36 & 0.42 & 7.3 \\
\hline 24.09 .2017 & 4.5 & 69 & 2.25 & 2.84 & 2.25 & 0.44 & 5.8 \\
\hline 07.11 .2017 & 4.4 & 143 & 2.36 & 2.84 & 2.36 & 0.42 & 9.3 \\
\hline 24.11 .2017 & 5.1 & 92 & 2.36 & 2.60 & 2.36 & 0.42 & 11 \\
\hline 26.07 .2018 & 4.5 & 89 & 2.36 & 2.84 & 2.47 & 0.40 & 7.2 \\
\hline Ortalama & & & & & 2.36 & 0.42 & 7.5 \\
\hline
\end{tabular}

Yapılan tüm depremlerin SSR yöntemine analizleri Şekil 3.6' da gösterilmeye çalışılmış, Şekil 3.7'de 9 adet depremin ortalaması alınarak çalışmanın sonucuna ulaşılmıştır.

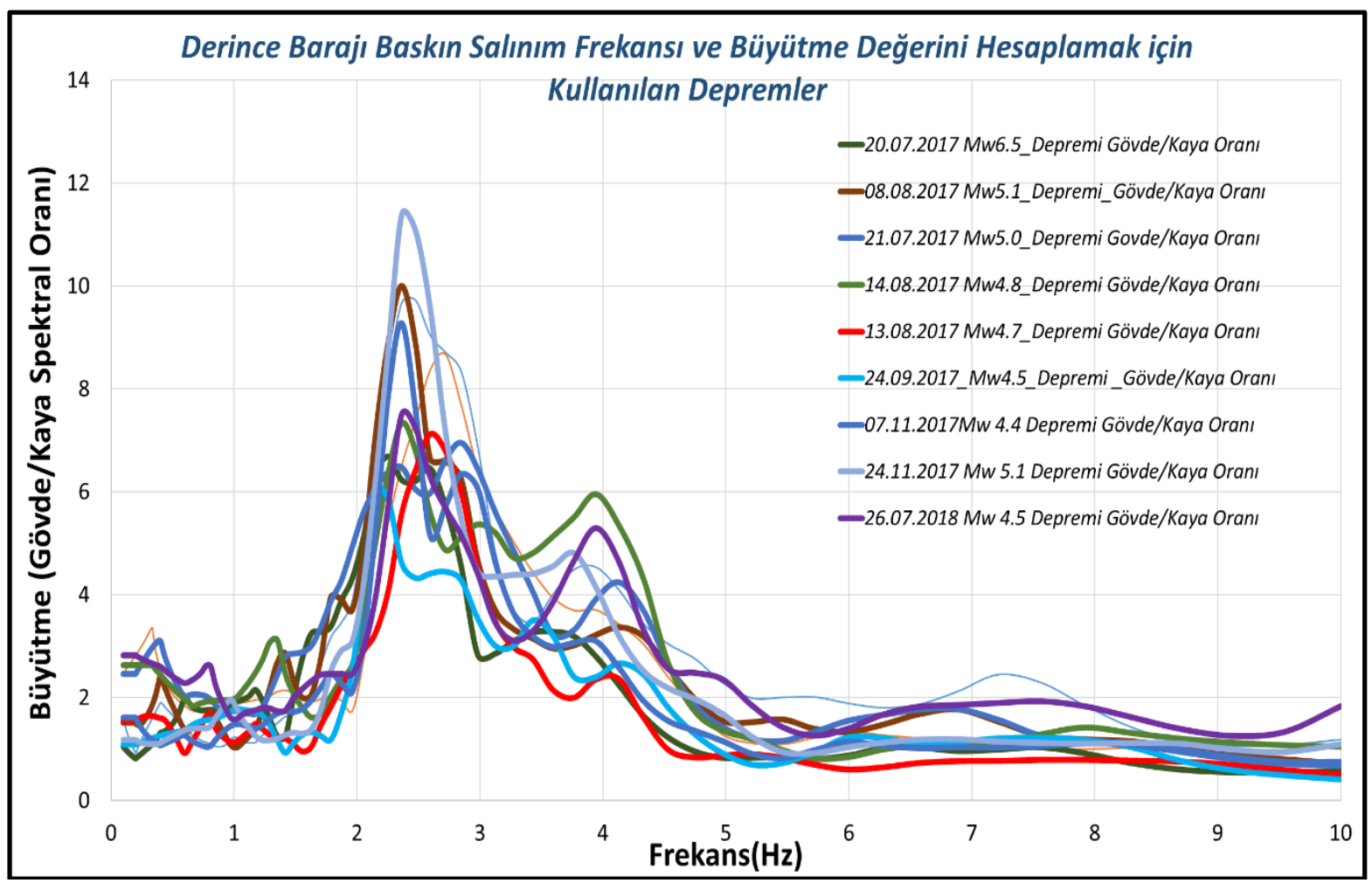

Şekil 3.6. Çalışmada kullanılan 9 adet depremin sonuçları (ssr yöntemi) 


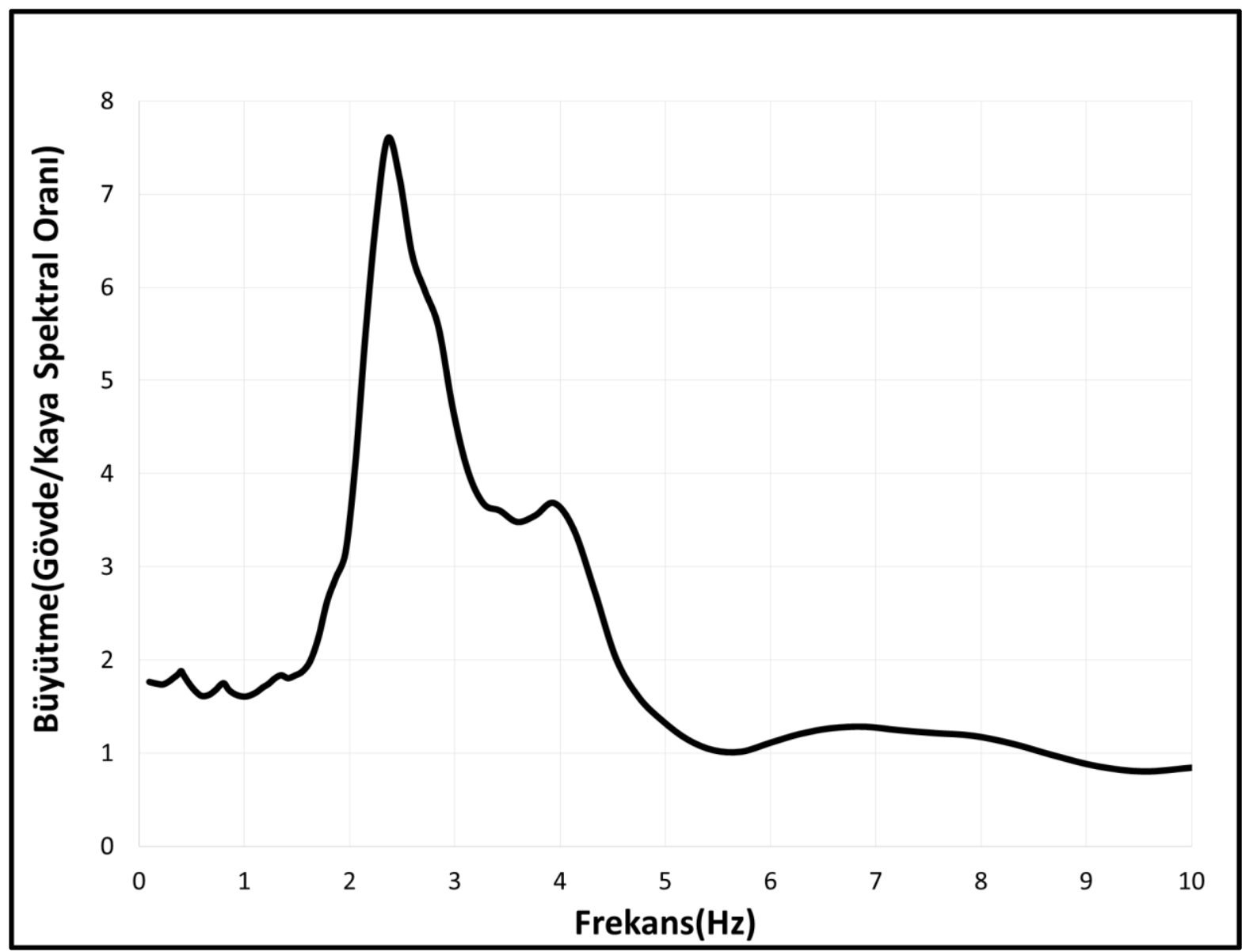

Şekil 3.7. Derince baraj gövdesinin farklı depremlere bağlı ortalama spektral oran büyütmesi (ssr yöntemi)

\subsection{HVSR Yöntemi}

Bir ivmeölçer istasyonunda kaydedilen deprem kaydının S fazının iki yatay bileşenlerin genlik spektrumunun, düşey bileşene oranlanması prensibine dayanır (Nakamura, 1989; Lermo J ve ark., 1993).

Deprem kayıtlarında düşey bileşenin yer özelliklerinden etkilenmediği fakat yatay bileşenlerin, yer tabakalarının yoğunluk ve hız özellikleri farklılıklarına bağlı olarak deprem dalgalarının genliklerini belli frekanslarda büyütmektedir. Yatay bileşenlerin düşey spektruma oranlanması ile yere veya yapıya ait transfer fonksiyonunun hesaplanması sağlanır. Kısaca bu yöntem düşey bileşeni referans olarak kabul eder.

$$
S t=H y \div V d
$$

Eşitlik 2'de verilen Hy yatay bileşen spektrumlarının bileşkesini Vd düşey bileşen spektrumunu St transfer fonksiyonunu göstermektedir.

\subsubsection{HVSR Yönteminde Veri İşlem}

Analizde kullanılan depremler baraj gövdesinde bulunan ivmeölçer tarafından kayıt edilen 9 adet deprem olup Çizelge 2.1 de verilmiştir. HVSR yönteminde kullanılan depremler ile SSR yönteminde kullanılan depremler aynıdır. Gövde de bulunan ivmeölçer istasyonu kaydının 
yatay bileşen spektrumları düşey bileşene oranlanmıştır. Şekil 3.8-3.9'da örnek olarak 2 adet deprem kaydı gösterilmiştir.

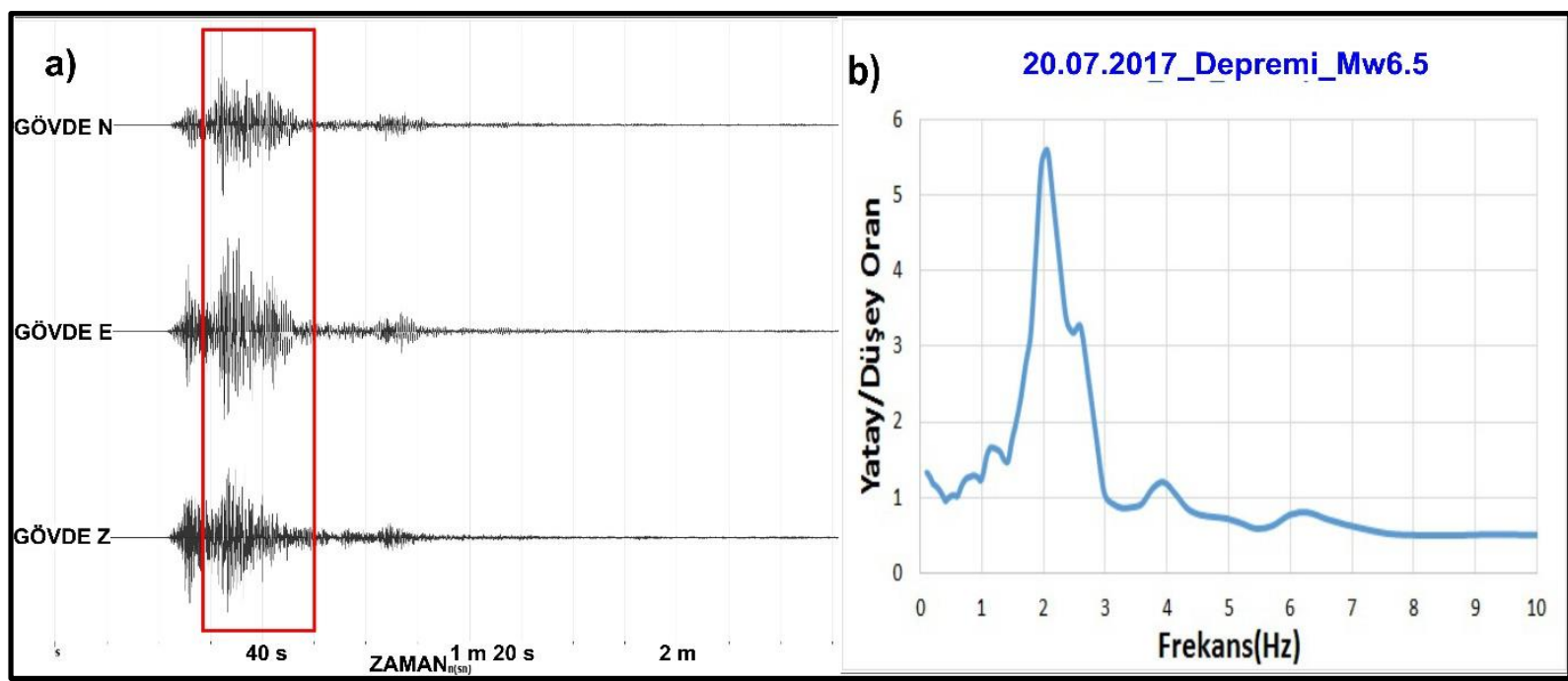

Şekil 3.8. a) 20.07.2017 Mw 6.5 depremi baraj gövdesi ivme kaydı ve seçilen S fazı, b) Gövdeye ait yatay/düşey oran spektrumu

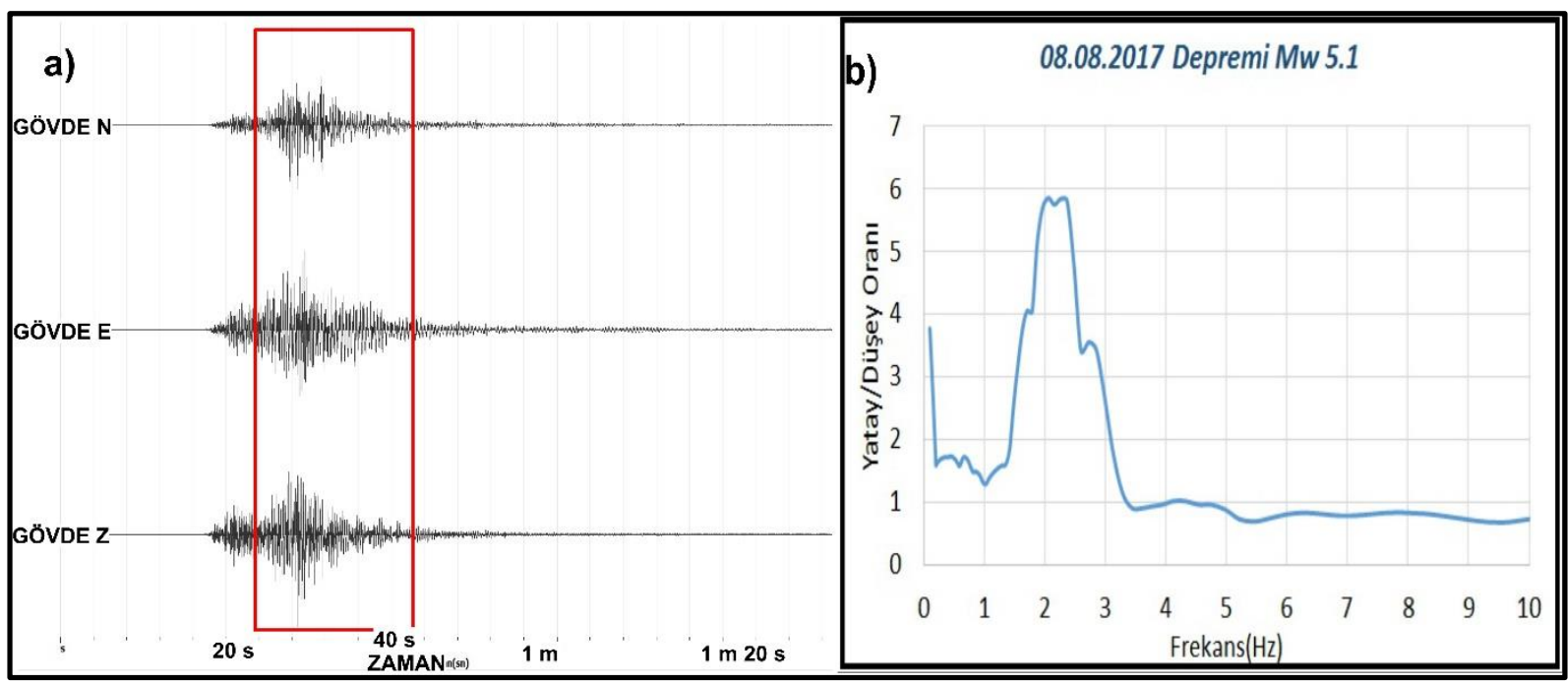

Şekil 3.9. a) 08.08.2017 Mw 5.1 baraj gövdesi ivme kaydı ve seçilen S fazı, b) Gövdeye ait yatay/düşey oran spektrumu

Çalışmada yapılan analizlerde GEOPSY programı kullanılmıştır (Sesame, 2004). Kullanılan kayıtların örnekleme aralığı saniyede 100 örnektir. Gövdeye ait büyütmenin tespiti için ivmekaydının S dalga fazı kullanılmıştır. Belirlenen S fazından 5 sn uzunlukta pencereler kesilerek filtre işlemi uygulanmış ve veri uçları başından ve sonundan yuvarlatılarak hızlı Fourier dönüşümü kullanılarak genlik spektrumları alınmıştır. Yatay bileşen spektrumu düşey bileşene oranlanmıştır.

Baraj gövdesinde bulunan yatay bileşen kayıtları düşey bileşene oranlanarak transfer fonksiyonu hesaplanmıştır. Her bir deprem için gövdeye ait 1. Mod frekansı ve büyütme değeri bulunmuş, 9 depreme ait değerlerin ortalaması alınarak baraj gövdesinin 1. Mod frekansı hesaplanmiştır. 


\subsubsection{HVSR Yöntemi Sonuçları}

Yapılan 9 adet deprem çalışmasında baraj gövdesinde bulunan ivmeölçer istasyonunun kaydettiği ivme kayıtları HVSR yöntemlerine göre değerlendirilmiş hakim frekansları bulunmuştur.

Baraj gövdesinde yapılan 9 adet depreme ait çalışmada baraj gövdesinin baskın salınım frekans1 $2.36 \mathrm{~Hz}$ bulunmuştur. Bu çalışmamızda yön bağımlılığından kurtulmak için eksenler birleştirilmiştir. Sonuçlar Çizelge 3.2'de gösterilmiştir. Tüm depremlere ait sonuçları Şekil 3.10, 9 depreme ait analizlerin ortalamasını Şekil 3.11 'de görmekteyiz.

Çizelge 3.2. Çalışmada kullanılan depremlere ait analiz sonuçları

\begin{tabular}{|c|c|c|c|c|c|}
\hline Tarih & $\begin{array}{c}\text { Büyüklük } \\
(\mathrm{Mw})\end{array}$ & $\begin{array}{c}\text { İstasyona olan } \\
\text { uzaklık (km) }\end{array}$ & $\begin{array}{c}\text { Hakim } \\
\text { Frekans(f0) } \\
\mathrm{Hz}\end{array}$ & $\begin{array}{c}\text { Hakim } \\
\text { Periyod(To) } \\
\text { sn }\end{array}$ & Büyütme \\
\hline 20.07 .2017 & 6.5 & 53 & 2.05 & 0.49 & 5.7 \\
\hline 08.08 .2017 & 5.1 & 54 & 2.36 & 0.42 & 5.8 \\
\hline 21.07 .2017 & 5.0 & 62 & 2.25 & 0.44 & 6.4 \\
\hline 13.08 .2017 & 4.8 & 37 & 2.47 & 0.40 & 8.2 \\
\hline 14.08 .2017 & 4.7 & 36 & 2.47 & 0.40 & 10 \\
\hline 24.09 .2017 & 4.5 & 69 & 2.25 & 0.44 & 6 \\
\hline 07.11 .2017 & 4.4 & 143 & 2.36 & 0.42 & 8.7 \\
\hline 24.11 .2017 & 5.1 & 92 & 2.25 & 0.44 & 7.3 \\
\hline 26.07 .2018 & 4.5 & 89 & 2.36 & 0.42 & 7.9 \\
\hline Ortalama & & & 2.36 & 0.42 & 7.0 \\
\hline
\end{tabular}




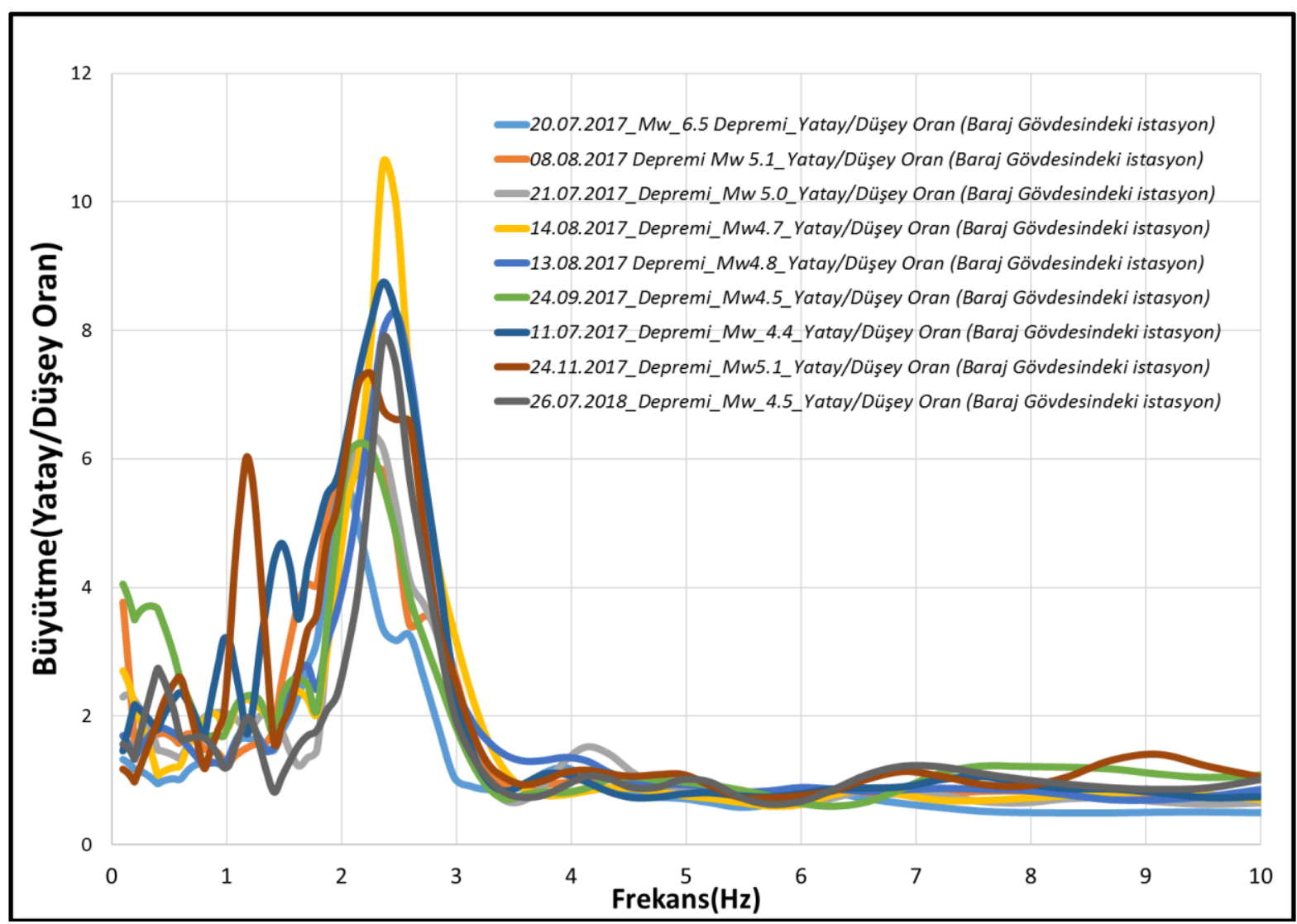

Şekil 3.10. Çalışmada kullanılan 9 adet depremin sonuçları (ssr yöntemi)

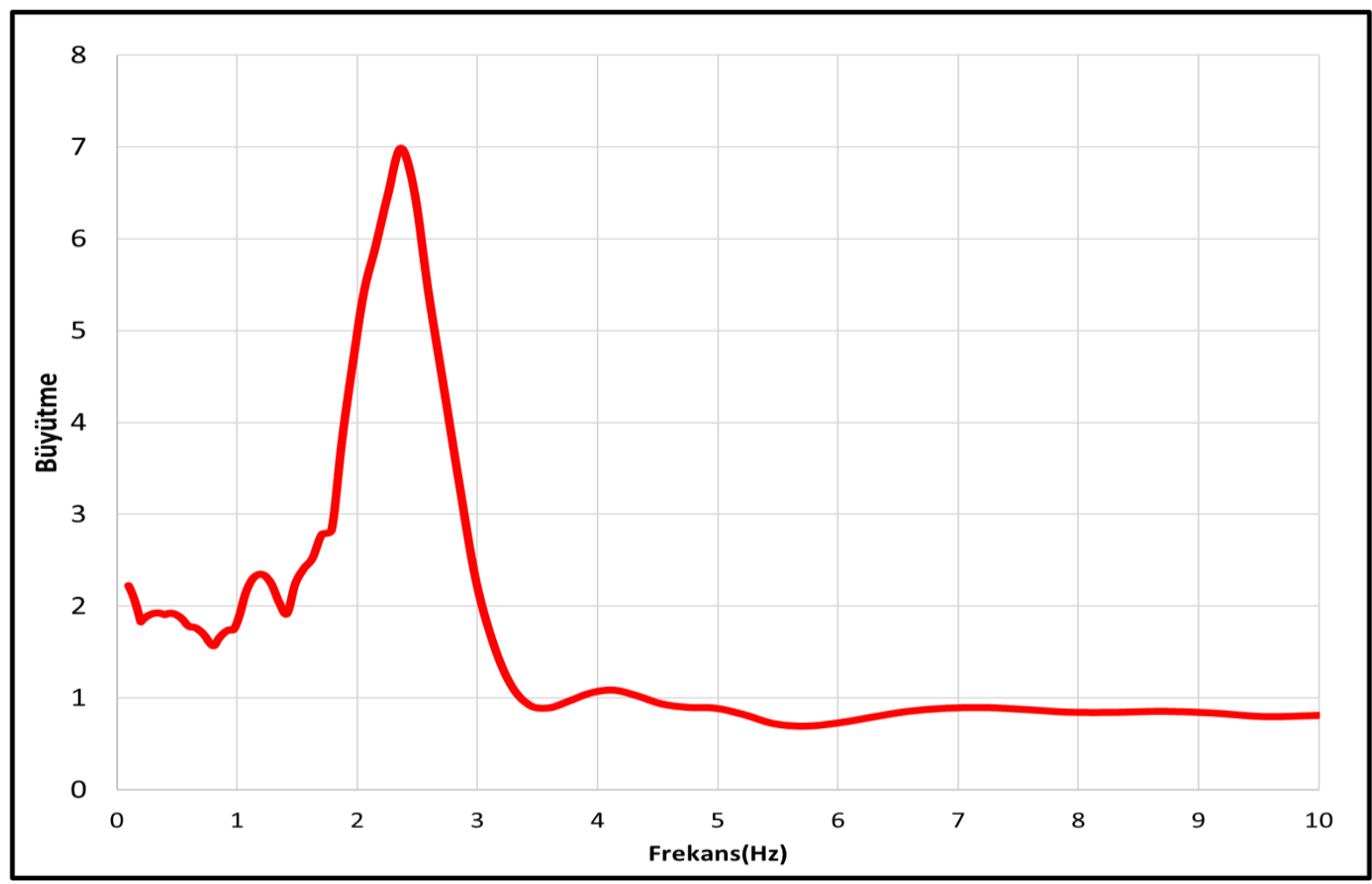

Şekil 3.11. Derince Baraj gövdesinin farklı depremlere bağlı ortalama yatay/düşey spektral oran büyütmesi (HVSR yöntemi) 


\section{Yöntemlerin Karşılaştırılması}

Baraj gövdesinde ve ana kayada bulunan ivmeölçer istasyonlar tarafından kayıt edilen deprem (ivme kayıtları) iki farklı yönteme (SSR, HVSR) göre analiz edilmiş ve baraj gövdesine ait baskın salınım frekansları ve büyütme değerleri hesaplanmıştır.

Baraj gövdesinde $2.36 \mathrm{~Hz}$ frekansında bir büyütme belirlenmiştir. Bu frekansın baraj gövdesinin 1. Mod frekansı olduğu düşünülmektedir. Şekil 4.1 de iki farklı yöntemin sonuçlarını görmekteyiz. İki farklı yöntemin (SSR, HVSR) analizinde aynı frekanslarda büyütme değerleri hesaplanmıştır. Sonuçlara bakıldığında iki yöntemin birbiri ile uyumlu olduğu görülmektedir. İki yöntemle de aynı hakim frekans değeri hesaplanmış yalnızca büyütme değerinde ufak bir farklılık olduğu görülmüştür. İki yöntem arasındaki büyütme farkı yaklaşık olarak \%7 civarındadır. Bu çalışmadan da görüleceği üzere iki farklı yöntemde yer/yapı çalışmalarında başarı ile kullanılabileceği görülmüştür. İki farklı yöntemin sonuçları birbirine çok yakındır.

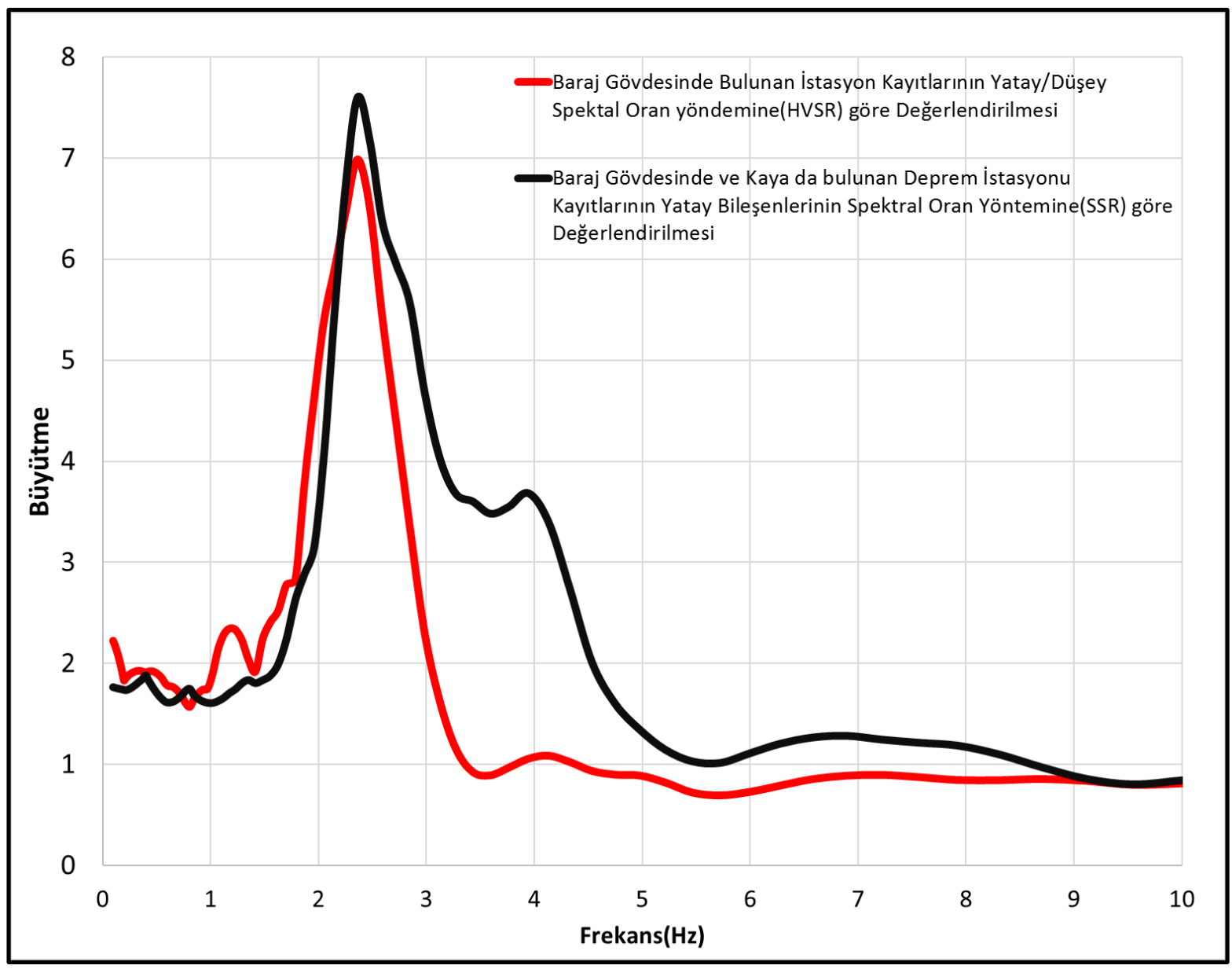

Şekil 4.1. SSR ve HVSR yöntemlerinin karşılaştırılması

\section{Sonuçlar}

Derince Barajında gövde üzerinde ve ana kayada bulunan barajın deprem durumundaki davranışını takip etmek sebebi ile kurulan ivmeölçer cihazlarının kaydettiği deprem kayıtlarının iki farklı (SSR, HVSR) analiz yöntemi ile değerlendirilmiş, baraj gövdesinin dinamik özellikler belirlenmeye çalışılmıştır. 
Alınan deprem kayıtlarından yapılan analizlerin ortak sonucu olarak iki farklı yöntemle barajın hakim (1. Mod) frekansı $2.36 \mathrm{~Hz}$ (periyot $0.42 \mathrm{sn}$ ) hesaplanmıştır. Yapılan 9 adet analizde benzer sonuçlara ulaşılmış bu frekansın barajın 1. Mod frekansı olduğu sonucuna varılmıştır. Ulaşılan sonuçlar çalışmanın ilk çıktıları olup uygun sayıda büyüklükte deprem meydana geldikçe çalışma güncellenecektir. Ayrıca frekans değişiminin deprem büyüklüğüne bağlı olarak değişimi ve yüksek mod frekansları daha detaylı incelenmelidir.

Bu çalışmada da görüleceği üzere iki farklı yöntemin (SSR ve HVSR) yer ve yapı çalışmalarında başarılı bir şekilde kullanılabileceği görülmüştür. İki yöntemin sonucunda çok az farklıliklar bulunmakta olduğu görülmektedir.

$\mathrm{Bu}$ çalışmanın sonuçları ile gerçek deprem ivme kayıtları girdi hareket olarak kullanılıp dinamik analiz yapılarak sonuçlar karşılaştırılmalı ve irdelenmelidir. Ayrıca bu çalışma sonuçları ile barajın tasarım aşamasındaki parametrelerin karşılaştırılması uygun olacaktır.

Barajlara kurulacak olan ivmeölçer cihazlarının barajların dinamik özellikleri hakkında vereceği bilgilerin ne kadar önemli olduğu görülmektedir. İlgili kurumlar tarafından barajlardan elde edilecek veriler takip edilmeli ve ortaya çıkan sonuçlar irdelenmelidir.

\section{Teșekkür}

Deprem verilerinin kaydedilmesi ve arşivlenmesini sağlayan DSİ, AFAD Deprem Dairesi Başkanlığı çalışanlarına ve olumlu eleştirileri ile çalışmaya katkı koyan hakemlere sonsuz teşekkür ederiz. 


\section{Kaynakça}

Anonim, 2019. AFAD Deprem Dairesi Başkanlığı Türkiye Kuvvetli Yer Hareketi Veri Tabanı http://kyhdata.deprem.gov.tr/2K/kyhdata_v4.php, 05 Ekim 2019.

Ateş E., Uyanık O., 2019. Jeofizik Yöntemler ile Yer ve Yapı Etkileşimi. Süleyman Demirel Üniversitesi Fen Bilimleri Enstitüsü Dergisi, 23:46-60.

Borcherdt R. D., 1970. Effects of Local Geology on Ground Motion Near San Francisco Bay. Bulletin of The Seismological Society of America, 60: 29-61.

Dikmen, Ü., 2009. Statistical correlations of shear wave velocity and penetration resistance for soils. Journal of Geophysics and Engineering, 6: 61-72.

Emre Ö., Duman TY., Özalp S., Elmacı H., Olgun Ş., Saroğlu F., 2013. Active Fault Map of Turkey Mineral Research and Exploration General Directorate, Special Issue Series-30, Ankara-Turkey

Gök E., Keçecioğlu M., Çeken U., Polat O., 2012. İzmirnet İstasyonlarında Standart Spektral Oran Yöntemi Kullanılarak Zemin Transfer Fonksiyonlarının Hesaplanması. Dokuz Eylül Üniversitesi, Mühendislik Fakültesi, Mühendislik Bilimleri Dergisi, 14(41): 1-11.

Jafari M. K., Shafiee A., Razmkhah A., 2002. Dynamic Properties of Fine Grained Soils in South of Tehran. Journal of Seismology and Earthquake Engineering (JSEE), 4(1): 2535 .

Karabulut S., Tezel O., Ozcep F., Imre N., 2012. A Geophysical Study On Soil Conditions After Flooding Hazard In Selimpasa, Istanbul (Turkey), Current Science, 102(2): 320326.

Konno, K., Ohmachi, T., 1998. Ground-Motion Characteristics Estimated from Spectral Ratio between Horizontal and Vertical Components. Bulletin of the Seismological Society of America, 88(1): 228-241.

Lermo J., Chavez G. F. J., 1993. Site Effect Evaluation Using Spectral Ratios with Only One Station. Bulletin Seismological Society of America, 83: 1574-1594.

Nakamura Y., 1989. A Method for Dynamic Characteristics Estimation of Subsurface Using Microtremor on the Ground Surface. Quarterly Report of the Railway Technical Research Institute, 30(1): 25-33.

Okur H.D., Gelişli K., Babacan A.E., Sesli H., 2019. Betonarme Yapılarda Gerilmenin Neden Olduğu Deformasyonların Jeofizik Yöntemlerle Araştırılması. Yerbilimleri, 40(1): 92109. 
Othman A.A.A., 2005. Construed geotechnical characteristics of foundation beds by seismic measurements. Journal of Geophysics and Engineering 2: 126-138.

Ozcep F., Karabulut S., Korkmaz B., Zarif H., 2010, Seismic Microzonation Studies in Sisli / Istanbul (Turkey), Scientific Research and Essay, 5(13): 1595 - 1614.

Özçelik E., Gelişli K., 2018. Investigation of Concrete Quality and Structure Reinforcement Conditions in Reinforced Concrete Structures by Geophysical Methods. Journal of Applied Earth sciences 17(1): 1-11.

Öziçer S., Uyanık O., 2017. Beton Dayanımının Yerinde P Dalga Hızından Belirlenmesi ve İzmir Örneği. SDU International Journal of Technological Sciences, 9(1): 1-16.

Pitilakis K., 2004. Site Effects, Recent Advances in Earthquake Geotechnical Engineering and Microzonation, Ansal (Ed), Kluwer Academic Publishers, Dordrecht, the Nederland, $354 \mathrm{p}$

Sabbağ N., Uyanık O., 2017. Prediction of Reinforced Concrete Strength by Ultrasonic Velocities. Journal of Applied Geophysics, 141: 13-23.

Sabbağ N., Uyanık O., 2018. Determination of the reinforced concrete strength by apparent resistivity depending on the curing conditions. Journal of Applied Geophysics, 155: 1325.

Salem H. S., 2000. Poisson's Ratio and the Porosity of Surface Soils and Shallow Sediments Determined from Seismic P and S-Wave Velocities. Geotechnique, 50(4): 461-463.

Sesame, 2004. Guidelines for the Implementation of the H/V Spectral Ratio Technique on Ambient Vibrations, Measurements Processing and Interpretation.

Steidl J. H., Tumarkin A. G., Archuleta R. J., 1996. What is a reference side? Bull Seism. Soc. Am., 86: 1733-1748.

Ulugergerli E. U., Uyanık O., 2007. Statistical correlations between seismic wave velocities and SPT blow counts and the relative density of soils. Journal of Testing and Evaluation, 35(2): 187-191.

Uyanık O., Ulugergerli E.U., 2008. Quality Control of Compacted Grounds Using Seismic Velocities, Near Surface Geophysics, 6(5): 299-306.

Uyanik O., 2010. Compressional and shear-wave velocity measurements in unconsolidated the top-soil and comparison of the results.International Journal of the Physical Sciences 5(7): 1034-1039.

Uyanık O., 2011. The Porosity of Saturated Shallow Sediments from Seismic Compressional and Shear Wave Velocities, Journal of Applied Geophysics,73(1): 16-24. 
Uyanık O., Kaptan K., Gülay F.G., Tezcan S., 2011. Beton Dayanımının Tahribatsız Ultrasonik Yöntemle Tayini. Yap1 Dünyası 184: 55-58.

Uyanık O., Çatlığlu B., Uyanık N.A., Öncü Z., Sabbağ N., 2012. Kentsel Dönüşüm Projelerinde Betonarme Yapıların Beton Kalitesinin Sismik Ultrasonik Hizlardan Belirlenmesi. 1. Yerbilimleri Sempozyumu, 18-20, Isparta.

Uyanık O., Ekinci B., Uyanık N.A., 2013a. Liquefaction Analysis from Seismic Velocities and Determination of Lagoon Limits Kumluca /Antalya Example. Journal of Applied Geophysics 95: 90-103.

Uyanık A.N., Uyanık O., Akkurt İ., 2013b. Micro-Zoning of the Natural Radioactivity Levels and Seismic Velocities of Potential Residential Areas in Volcanic Fields: The Case of Isparta (Turkey). Journal of Applied Geophysics, 98: 191-204

Uyanık O., 2015. Deprem Ağır Hasar Alanlarının Önceden Belirlenmesi ve Şehir Planlaması içinMakro ve Mikro Bölgelendirmelerin Önemi. Süleyman Demirel Üniversitesi Fen Bilimleri Enstitüsü Dergisi 19(2): 24-38.

Yalçınkaya E., Alptekin Ö., 2003. Dinar'da zemin büyütmesi ve 1 Ekim 1995 depreminde gözlenen hasarla ilişkisi. Hacettepe Üniversitesi, Yerbilimleri Uygulama ve Araştırma Merkezi Bülteni,27: 1-13.

Yalçınkaya E., 2005. BYT-Net (Bursa-Yalova-Türkiye İvme Ölçer Ağı) İstasyonlarında Yerel Zemin Etkilerinin İncelenmesi. Fen ve Mühendislik Dergisi, 7(2): 75-86, Dokuz Eylül Üniversitesi Mühendislik Fakültesi, İzmir. 